\title{
Relationship between vascular adrenergic receptors and prostaglandin biosyntheses in canine diabetic coronary arteries
}

\author{
M.Z.Koltai ${ }^{1}$, P.Rösen ${ }^{2}$, P. Hadházy ${ }^{3}$, Gy. Ballagi-Pordány ${ }^{1}$, A. Köszeghy ${ }^{1}$ and G.Pogátsa ${ }^{1}$ \\ ${ }^{1}$ National Institute of Cardiology, Budapest, Hungary, ${ }^{2}$ Diabetes Research Institute, Düsseldorf, FRG, and \\ ${ }^{3}$ Department of Pharmacodynamics, Semmelweis Medical School, Budapest, Hungary
}

\begin{abstract}
Summary. Before the onset of histologically detectable alterations of diabetic arteries, a considerable decrease of vasodilation ability develops. The role of an altered prostaglandin biosynthesis in this phenomenon was investigated in connection to the altered vascular adrenergic mechanisms. The effect of phenylephrine on prostacyclin production of isolated coronary arterial rings $(100 \mu \mathrm{mol} / \mathrm{l})$ as well as on conductivity of the coronary arterial bed (7.5-15-30-60 pmol. $\mathrm{kg}^{-1} \cdot \min ^{-1}$ ) were compared in 12 metabolically healthy and 12 alloxan-diabetic $(560 \mu \mathrm{mol} / \mathrm{kg})$ dogs. Furthermore, the effect of phentolamine $(5 \mu \mathrm{mol} / \mathrm{l})$ on the prostacyclin and thromboxane productions of the isolated vessels (coronary, femoral and basilar arteries) was investigated by radioimmunoassay. Although the basal prostacyclin amounts synthesized by healthy and diabetic coronary vessels were not different $(5.1 \pm 1.6$ and $4.9 \pm 1.4 \mathrm{pg} / \mathrm{mg}$ vessel $/ 30 \mathrm{~min})$, similarly to femoral and basilar arteries, the diabetic arterial rings produced significantly $(p<0.05)$ more thromboxane than the control rings. The $\alpha$-adrenergic blockade by phentolamine
\end{abstract}

did not influence the prostacyclin production in the healthy arteries, but considerably $(p<0.05)$ increased it in the diabetic coronary arteries. Phentolamine normalised the thromboxane synthesis in the diabetic group $(p<0.01)$ and enhanced $(p<0.05)$ it in the metabolically healthy group. Phenylephrine was ineffective $(98 \pm 6 \%)$ on the prostacyclin production in vitro versus the stimulated $(150 \pm 22 \%)$ prostacyclin synthesis detected in the metabolically healthy group; and in vivo induced a more significant $(p<0.05)$ decrease in the coronary conductivity in diabetic than in control groups. These results refer to the supposition that altered adrenergic mechanisms are involved in the imbalance of the vasoactive prostaglandins contributing to the high incidence of ischaemic heart disease in diabetes mellitus.

Key words: Alloxan-diabetes, coronary artery, $\alpha$-adrenergic receptors, prostacyclin, thromboxane, phenylephrine, phentolamine.
It is known that both the adrenergic receptor agonists [1] and the prostaglandins synthesized by the vascular tissue [2] may be involved in the regulation of coronary circulation. It has also been established that the reactivity of the diabetic vasculature to anoxia, hypercapnia, neurotransmitters and adrenergic stimuli is significantly modified [3-5]. Having been normalised under the influence of insulin, these pathological reactions are supposed to be the consequences of the metabolic disorder [6]. Disregarding a few exceptions [7, 8] most of the data demonstrate a vascular hypersensitivity against catecholamines in isolated diabetic mesenteric [9] and carotid [10] arteries as well as in rat [11, 12] and rabbit [13] aortae. On the other hand, a hyper-reactivity of the diabetic vascular tíssue to vasoconstrictor eicosanoids $[14,15]$ has also been demonstrated. In iso- lated coronary strips of alloxan-diabetic dogs prostaglandin (PG) $\mathrm{F}_{2 \alpha}$ exerted a significantly higher toneenhancing effect compared with metabolically healthy reactions [16] in the presence of cyclooxygenase inhibitor. A diminished synthesis of prostacyclin $\left(\mathrm{PGI}_{2}\right)$ in the isolated diabetic vessels and heart [17-20] on one hand, and an increased synthesis of thromboxane (TX) $\mathrm{A}_{2}$ [21] on the other indicate a pathological imbalance among the products of arachidonate cascade; especially that of $\mathrm{PGI}_{2} / \mathrm{TXA}_{2}$ ratio, which has been attributed as an important factor in the generation of vascular diseases [22].

It has been reported that under physiological circumstances catecholamines stimulate the release and synthesis of $\mathrm{PGI}_{2}$ in the myocardium [23]. However, it remains to be answered whether the altered adrenergic 
mechanisms and the altered prostaglandin biosynthesis in the diabetic vascular wall occur independently, or if these changes are causally related.

In order to clarify this potential relationship the following problems have been studied: (1) the influence of $\alpha$-adrenergic blockade on the production of $\mathrm{PGI}_{2}$ and $\mathrm{TXA}_{2}$ by coronary arteries; (2) the action of phenylephrine on $\mathrm{PGI}_{2}$ production by coronary artery rings from metabolically healthy and alloxan-diabetic dogs; (3) the effect of the $\alpha_{1}$-adrenergic receptor agonist phenylephrine on coronary conductivity in anaesthetised normal and alloxan-diabetic dogs.

\section{Materials and methods}

Twenty-four young mongrel dogs (15-34 kg) of both sexes, kept on the same diet consisting of $25 \%$ protein, $60 \%$ carbohydrate, $15 \%$ fat, vitamins and mineral salts ad libitum, were examined. Twelve dogs were made diabetic by alloxan $(560 \mu \mathrm{mol} / \mathrm{kg}$ i.v. Alloxan-tetrahydrate, Merck, Darmstadt, FRG), while the remaining twelve animals served as controls. Plasma disappearance rate of glucose [24], blood glucose [25] and urea nitrogen [26] levels were determined at the beginning of the study and subsequently once a month, while daily acetone [27] and glucose excretions [25] as well as body weight were measured at least once a week. Three months after the induction of diabetes, on the day before the examination, all the variables were redetermined.

Six metabolically healthy and six alloxan-diabetic dogs were anaesthetised $(133 \mu \mathrm{mol} / \mathrm{kg}$, Nembutal, Ceva, Paris, France), the heart was excised, the left anterior descending and circumflex coronary arteries removed, very cautiously freed from fat and adventitia were cut into 1-2 mm rings. To compare the basal values of arteries from different vascular regions basilar and femoral arteries were also cut out and similarly prepared. The arterial rings were placed into a bath of $3 \mathrm{ml}$ volume containing Krebs-Henseleit solution that was aerated with a mixture of $95 \% \mathrm{O}_{2}$ and $5 \% \mathrm{CO}_{2}$. The bathing fluid was replaced with fresh Krebs-Henseleit solution every $30 \mathrm{~min}$. In order to avoid an artificial increase of prostaglandin formation described after mechanical irritation [28] and to reach a stable minimal output of same, [29], the samples collected were used for assaying prostanoid production after a $2 \mathrm{~h}$ equilibrium period.

The vessel rings were divided into two groups. The first was placed into normal Krebs-Henseleit solution, while the second one into a bath containing $5 \mu \mathrm{mol} / 1$ phentolamine (Regitin, Ciba-Geigy, Basle, Switzerland). In this way all interventions were also carried out in $\alpha$-adrenergic blockade.

Adrenergic stimulus was produced by $100 \mu \mathrm{mol} / \mathrm{l}$ phenylephrine (phenylephrine hydrochloride, Serva, Heidelberg, FRG). 6-oxo$\mathrm{PGF}_{\alpha}$ and $\mathrm{TXB}_{2}$ were determined by selective radioimmunoassay [19]. The diluted samples were incubated overnight with antiserum $\left({ }^{\circ} \mathrm{C} 4\right.$; Pasteur Institute, Paris, France). Free tracer was separated from antibody-bound tracer by precipitation using the polyethylene glycol method. Radioactivity was determined after addition of $0.5 \mathrm{ml}$ of $1 \%$ sodium dodecyl sulphate (Pierce Chem. Comp., Rockford, Ill., USA) and $3 \mathrm{ml}$ liquid scintillation cocktail (Quickszint, Zinsser, Frankfurt, FRG) by a $\beta$-counter (Kontron, Münchenstein, Switzerland). All samples were assayed in triplicate in a single assay. The sensitivity of the method was $10 \mathrm{pg} / \mathrm{ml}$, interassay variation $10 \%$ and intra-assay variation $<3 \%$.

In the remaining six metabolically healthy and six alloxandiabetic dogs under pentobarbital anaesthesia the chest was opened, the left anterior descending coronary artery exposed and its blood flow measured by an electromagnetic flowmeter (Godard Statham, SP 2202). Arterial blood pressure was determined in the thoracic aorta through the femoral artery with a Statham gauge (P23Db). A polyaethylene cannula was inserted through a collateral branch into the coronary artery for drug infusion. After recording of the basal values on a multiscriptor (Medicor, R-61) 7.5-15-30-60 pmol. $\mathrm{kg}^{-1} \cdot \min ^{-1}$ phenylephrine was infused until the steady state was reached. The conductivity of the coronary arterial bed was calculated by the flow/pressure ratio.

\section{Statistical analysis}

The synthesized prostaglandin amounts were expressed in $\mathrm{pg} / \mathrm{mg}$ vascular tissue $/ 30 \mathrm{~min}$. The alteration of the conductivity of the coronary arterial bed in the presence of phenylephrine was expressed in a percentage of the basal value. The results given as means \pm SEM were evaluated by using Student's paired or unpaired t-tests as well as regression analysis.

\section{Results}

Plasma disappearance rate of glucose and body weight decreased after alloxan-treatment $(p<0.001)$, whereas fasting blood glucose level and urinary glucose excretion increased $(p<0.001)$. Acetone excretion was never detected. Animals with enhanced blood urea nitrogen level were excluded from the study. These changes strongly suggest the presence of a manifest form of diabetes mellitus (Table 1).

In the basal state there were no significant differences between the amounts of $\mathrm{PGI}_{2}$ produced by metabolically healthy and alloxan-diabetic isolated vessel rings from the basilar, coronary or femoral arteries (Table 2). However, it was remarkable that the $\mathrm{PGI}_{2-}$ synthesizing capacity of the basilar artery was much higher than those of the coronary and femoral arteries.

In relation to $\mathrm{TXA}_{2}$ production, a significantly higher rate of synthesis $(p<0.05 ; p<0.01)$ could be

Table 1. Metabolic state of control and alloxan-diabetic dogs

\begin{tabular}{|c|c|c|c|c|}
\hline & $\begin{array}{l}\text { Plasma disappearance } \\
\text { rate of glucose } \\
(\mu \mathrm{mol} / \mathrm{min})\end{array}$ & $\begin{array}{l}\text { Plasma } \\
\text { glucose } \\
(\mathrm{mmol} / 1)\end{array}$ & $\begin{array}{l}\text { Glucose } \\
\text { excretion } \\
\text { (mmol/day) }\end{array}$ & $\begin{array}{l}\text { Body } \\
\text { weight } \\
(\mathrm{kg})\end{array}$ \\
\hline $\begin{array}{l}\text { Control }(n=12) \\
\text { Diabetic }(n=12)\end{array}$ & $16 \pm 1$ & $5.4 \pm 0.4$ & 0 & $23.0 \pm 3.9$ \\
\hline $\begin{array}{l}\text { before alloxan } \\
\text { after alloxan }\end{array}$ & $\begin{array}{c}15 \pm 1 \\
5 \pm 1^{\mathrm{a}}\end{array}$ & $\begin{array}{c}5.2 \pm 0.3 \\
13.8 \pm 4.2^{\mathrm{a}}\end{array}$ & $\begin{array}{l}0 \\
68 \pm 74^{\mathrm{a}}\end{array}$ & $\begin{array}{l}23.2 \pm 1.7 \\
20.3 \pm 1.7\end{array}$ \\
\hline
\end{tabular}

Data are expressed as mean \pm SEM. significance referred to values obtained before alloxan treatment is indicated by: ${ }^{a} p<0.001$ 

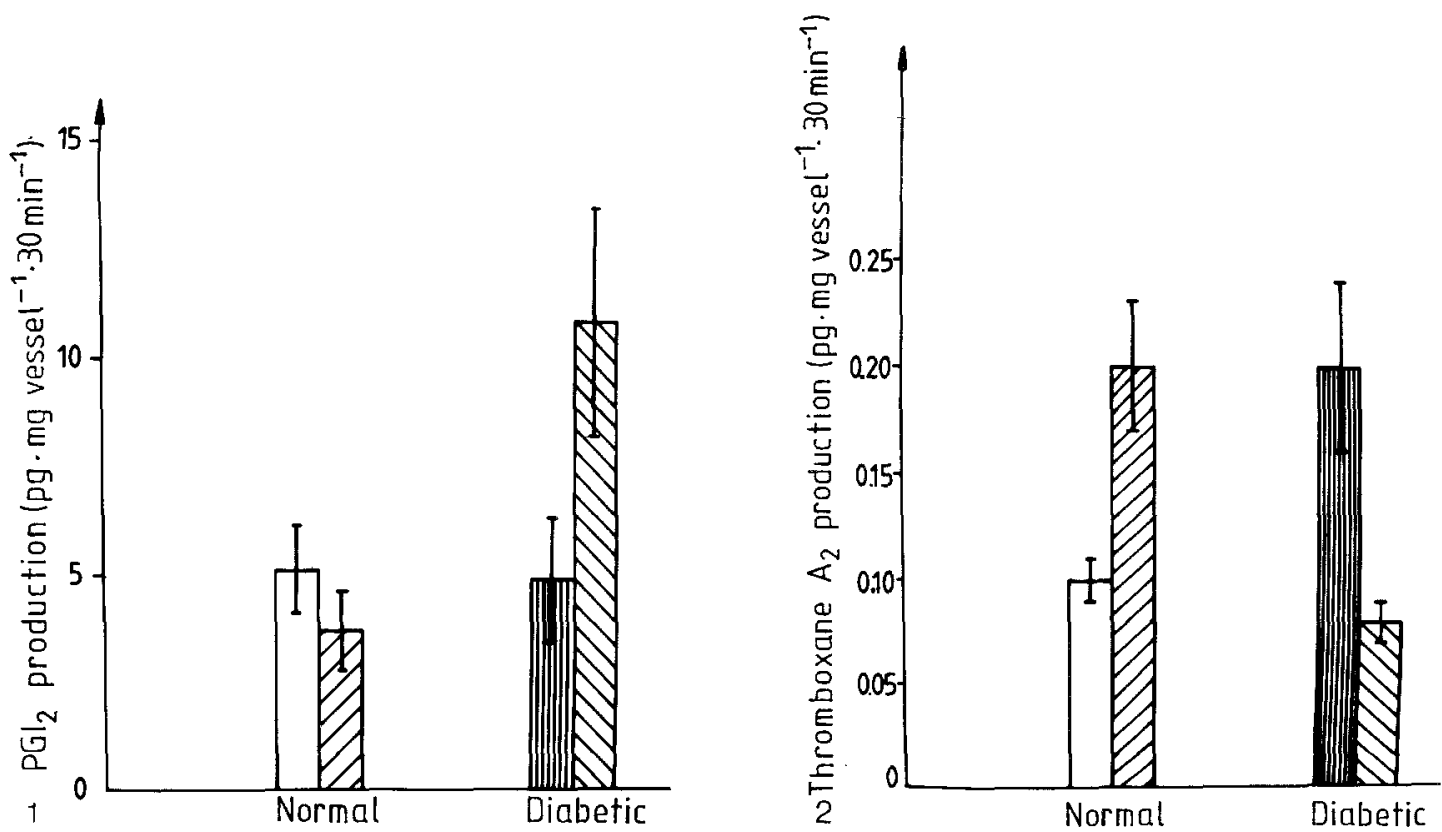

Fig. 1. Effect of phentolamine $(5 \mu \mathrm{mol} / \mathrm{l})$ on $\mathrm{PGI}_{2}$ synthesis by isolated healthy and diabetic canine coronary arteries. Groups: metabolically healthy vessel rings without $\square$ and with $\mathbb{m}$ phentolamine treatment; alloxan-diabetic vessel rings without $\min$ and with phentolamine treatment. Each bar is the mean \pm SEM of 6-6 individual experiments. Significant differences refer to a comparison between the healthy phentolaminetreated and diabetic phentolamine-treated groups at a level of $p<0.01$, while between the non-treated and phentolamine-treated diabetic groups at a level of $p<0.05$

Fig.2. Effect of phentolamine $(5 \mu \mathrm{mol} / 1)$ on $\mathrm{TXA}_{2}$ synthesis by isolated healthy and diabetic canine coronary arteries. Groups: metabolically healthy vessel rings without $\square$ and with $\mathbb{Z}$ phentolamine treatment; alloxan-diabetic vessel rings without Each bar is the mean \pm SEM of 6-6 individual experiments. Significant differences refer to a comparison between the non-treated healthy and diabetic groups at a level of $p<0.05$; between the phentolamine-treated healthy and diabetic groups at a level of $p<0.01$; between the healthy non-treated and phentolamine-treated animals at a level of $p<0.005$; between the non-treated and phentolamine-treated diabetic animals at a level of $p<0.01$

Table 2. Prostacyclin $\left(\mathrm{PGI}_{2}\right)$ and thromboxane $\left(\mathrm{TXA}_{2}\right)$ production $\left(\mathrm{pg} \cdot \mathrm{mg} \mathrm{vessel}^{-1} \cdot 30 \mathrm{~min}^{-1}\right)$ by various canine arteries

\begin{tabular}{llcc}
\hline & & $\begin{array}{l}\text { Metabolically } \\
\text { healthy } \\
n=6\end{array}$ & $\begin{array}{l}\text { Alloxan- } \\
\text { diabetic } \\
n=6\end{array}$ \\
\hline Basilar artery & $\mathrm{PGI}_{2}$ & $28.0 \pm 3.8$ & $39.0 \pm 6.0$ \\
& $\mathrm{TXA}_{2}$ & $0.8 \pm 0.1$ & $1.3 \pm 0.2^{\mathrm{a}}$ \\
Coronary artery & $\mathrm{PGI}_{2}$ & $5.1 \pm 1.60$ & $4.9 \pm 1.40$ \\
& $\mathrm{TXA}_{2}$ & $0.1 \pm 0.01$ & $0.2 \pm 0.04^{\mathrm{a}}$ \\
& $\mathrm{PGI}_{2}$ & $11.10 \pm 1.70$ & $10.70 \pm 3.10$ \\
& $\mathrm{TXA}_{2}$ & $0.13 \pm 0.01$ & $0.22 \pm 0.01^{\mathrm{b}}$ \\
\hline
\end{tabular}

Data expressed as mean \pm SEM. Significance refers to values obtained in the controls.

${ }^{\mathrm{a}} p<0.05 ;{ }^{\mathrm{b}} p<0.001$

detected in the diabetic arterial rings versus the controls (Table 2).

Whilst the basal synthesis of $\mathrm{PGI}_{2}$ was similar in normal and diabetic coronary artery rings, it was changed by phentolamine in the two groups of vessels differently. The $\alpha$-adrenoceptor antagonist failed to alter the basal $\mathrm{PGI}_{2}$ production by normal coronary rings. By contrast, this drug markedly increased $(p<0.01)$ the resting synthesis of $\mathrm{PGI}_{2}$ in diabetic vessels (Fig. 1).

Phentolamine also produced differential changes in the TXA $\mathrm{T}_{2}$ synthesis of normal and diabetic coronary arteries: the resting production of $\mathrm{TXA}_{2}$ was doubled in the former group of vessels, whereas it was considerably reduced $(p<0.01)$ in the latter vascular rings in the presence of the $\alpha$-adrenoceptor antagonist (Fig. 2).

In vitro phenylephrine increased the $\mathrm{PGI}_{2}$ amount synthesized by metabolically healthy coronary arterial rings, while it did not affect the $\mathrm{PGI}_{2}$ production of diabetic vessels (Fig. 3 ). In the metabolically healthy coronaries pretreatment with the $\alpha$-adrenergic blocker phentolamine prevented the enhancement of $\mathrm{PGI}_{2}$ release without altering the $\mathrm{PGI}_{2}$ amount synthesized by diabetic arterial rings.

It was interesting to see whether or not these phenylephrine-induced changes in $\mathrm{PGI}_{2}$ production resulted in alteration of the vasomotor responsiveness in vivo to the $\alpha$-adrenoceptor agonist. We found that intracoronarily-administered phenylephrine exerted a dose-dependent decrease in the conductivity of the coronary arterial bed (Fig.4). This effect of the $\alpha$-adrenergic agonist was much more expressed in alloxan-diabetic dogs than in metabolically healthy ones. 


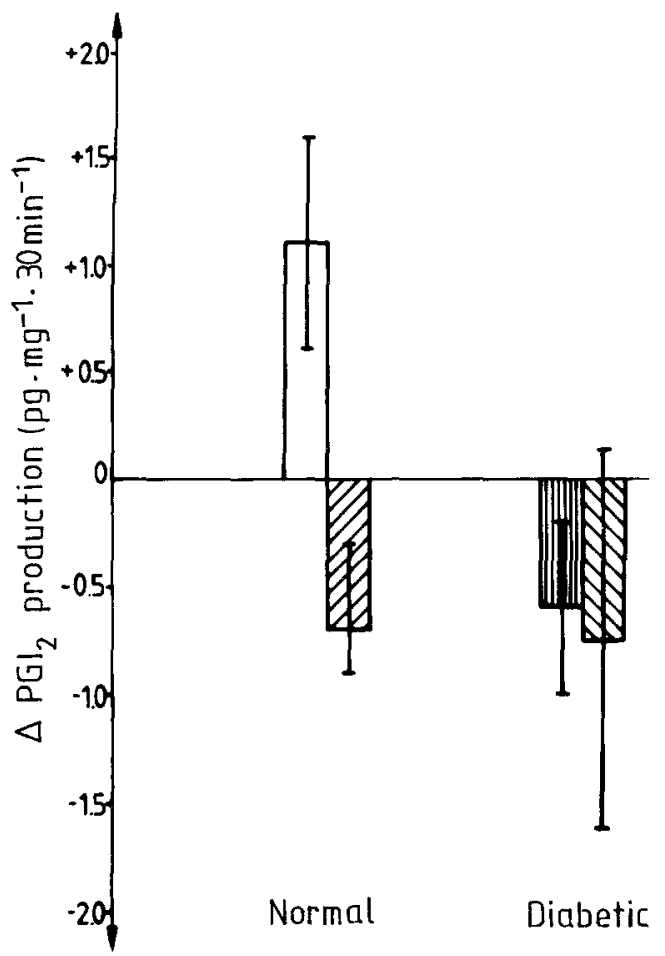

Fig.3. Phenylephrine $(100 \mu \mathrm{mol} / 1)$-induced alteration in $\mathrm{PGI}_{2}$ synthesis by isolated healthy and diabetic canine coronary arteries. Groups: metabolically healthy vessel rings without $\square$ and with $\mathbb{Z}$ phentolamine $(5 \mathrm{umol} / \mathrm{l})$ treatment; alloxan-diabetic vessel rings without $\mathrm{m}$ and with phentolamine treatment. Each bar represents the mean alteration \pm SEM of 5-5 individual experiments. Significant differences refer to a comparison between healthy and diabetic non-treated dogs at a level of $p<0.05$; between the non-treated and phentolamine treated healthy groups at the level $p<0.01$

\section{Discussion}

Prostacyclin is known to be one of the most potent endogenous vasodilators in several vascular regions [2] including the coronary arterial bed. The majority of findings indicate that the synthesis of $\mathrm{PGI}_{2}$ by various vessels $[30,31]$ decreases both in experimental and clinical diabetes $[20,32,33]$. This alteration might be dependent on the duration [34] and degree [35] of the diabetic metabolic disorder. Furthermore, according to Myers et al. [35] and Roth et al. [15] diabetic large arteries synthesize and release less amounts of $\mathrm{PGI}_{2}$, while $\mathrm{PGI}_{2}$ production by the small arteries was demonstrated to increase.

In addition to $\mathrm{PGI}_{2}, \mathrm{TXA}_{2}$ also has to be considered in the regulation of local coronary circulation [36]. This latter cyclo-oxygenase product synthesized by the vascular wall $[37,38]$ seems also to be involved in maintaining balance [39] among vasoactive prostaglandins. This balance might be disturbed in diabetes not only in the platelets [40] but also in the vasculature $[17,41,42]$.

In our studies the basal $\mathrm{PGI}_{2}$ synthesis was similar in each investigated vessel obtained either from healthy or alloxan-diabetic dogs. Jeremy et al. [43] ob-

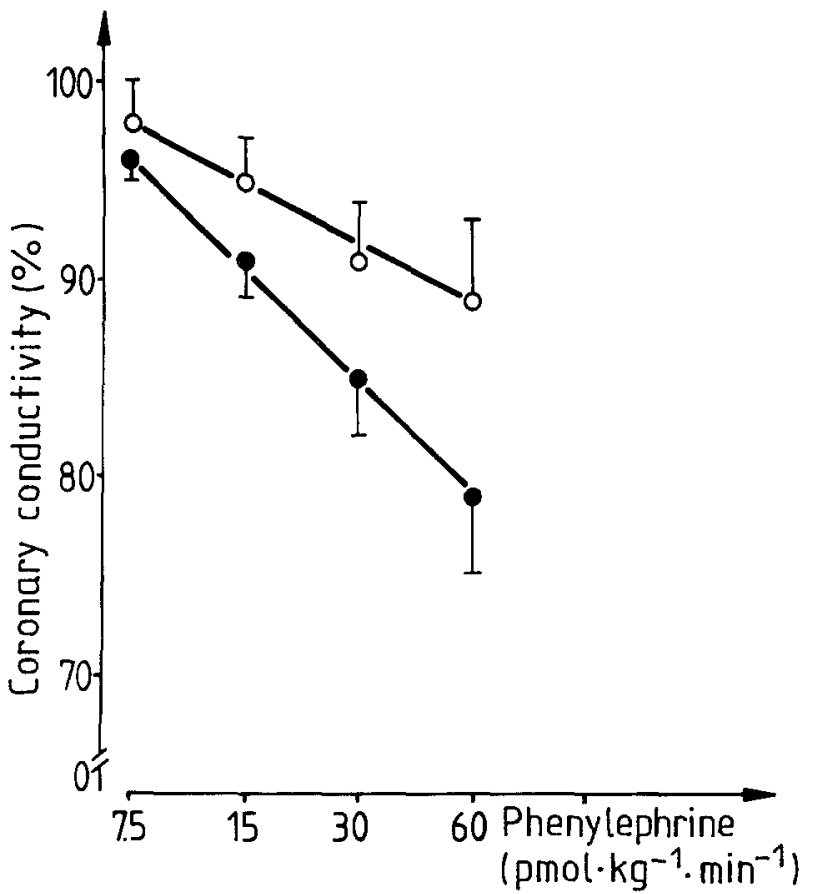

Fig.4. Effect of phenylephrine on the conductivity in the coronary arterial bed expressed in percentage of initial values in metabolically healthy $(O)$ and alloxan-diabetic $(O)$ dogs. Each bar is the mean \pm SEM of 6-6 individual experiments. Comparison was made between the slopes of the healthy and diabetic reactions representing a linear correlation. Significant difference was found at a level of $p<0.01$

served that the rate of $\mathrm{PGI}_{2}$ production by aortae of streptozotocin-diabetic rats was dependent on the duration and severity of the carbohydrate metabolic disorder. Thus our finding, i.e. the lack of effect of diabetes on basal $\mathrm{PGI}_{2}$ synthesis, might be explained by the mild form of the alloxan-induced disorder without acetonuria.

In contrast to the unchanged basal formation of $\mathrm{PGI}_{2}$, the synthesis of $\mathrm{TXA}_{2}$ by the coronary, femoral and basilar arteries was markedly enhanced in alloxan-diabetes. This observation is in accordance with the results of Fujii et al. [41] who reported that streptozotocin treatment increased the formation of $\mathrm{TXA}_{2}$ by the mesenteric vascular bed of rats. As shown in Table 2, the rate of $\mathrm{TXA}_{2}$ was about 15 to 20-fold less than that of $\mathrm{PGI}_{2}$. Although $\mathrm{TXA}_{2}$ is known to be a vasoconstrictor [44], nevertheless the importance of this very small quantity of $\mathrm{TXA}_{2}$ in the healthy local coronary circulation remains to be understood. On the other hand, the pathogenic role of elevated $\mathrm{TXA}_{2}$ formation in diabetes mellitus has to be considered.

Whereas the inhibition of the $\alpha$-adrenoceptors does not significantly affect the resting $\mathrm{PGI}_{2}$ production of the metabolically healthy coronary vessels (Fig.1), it enhances considerably that of the diabetic coronary arteries. The 'TXA 2 synthesis by the phentolamine-treated control and diabetic coronary arterial 
rings is oppositely altered (Fig. 2): in diabetes, TXA $_{2}$ formation was reduced by the $\alpha$-adrenoceptor antagonist to the control level, whilst it was markedly increased by the drug in healthy vessels. These data support the hypothesis that the relationship between the vascular $\alpha$-adrenergic receptors and basal prostaglandin production [45] may be altered in diabetes mellitus not only in vas deferens [46], but also in coronary arteries.

However, it is not only the vascular $\alpha$-adrenergic receptor in diabetes which influences the basal prostaglandin biosynthesis pathologically. The balance among the cyclo-oxygenase products must have been changed and disturbed independently of the function of $\alpha$-adrenoceptors, since (1) the basal TXA 2 production by diabetic coronary arteries proves to be higher versus that of healthy vessels and (2) phentolamine does not exert an opposite influence on $\mathrm{PGI}_{2}$ production - as was seen in the case of $\mathrm{TXA}_{2}$ formation - in the metabolically healthy and alloxan-diabetic vascular tissues.

Phenylephrine, as an exogenous adrenergic stimulus potentiated $\mathrm{PGI}_{2}$ production in isolated coronary rings from metabolically healthy dogs (Fig. 3). With this effect the vascular $\alpha$-adrenergic receptors are supposed to be specifically involved, since it could be prevented by phentolamine pretreatment. Phenylephrine does not exert a similar effect on $\mathrm{PGI}_{2}$ formation in the diabetic coronary vessels. This phenomenon might be due: (1) to a lack of available precursors for a stimulated $\mathrm{PGI}_{2}$ synthesis [47]; or (2) to the depression of $\mathrm{PGI}_{2}$ formation by activation of adrenergic vascular receptors. The latter supposition is supported by the considerable increase in $\mathrm{PGI}_{2}$ release from diabetic arteries, if the $\alpha$-adrenoceptors are blocked by phentolamine (Fig. 1). This hypothesis is also confirmed by the finding that phentolamine is not able to enhance the $\mathrm{PGI}_{2}$ synthesis in the presence of adrenoceptor agonist phenylephrine in diabetes mellitus (Fig. 3).

In this study, the $\alpha$-adrenoceptor agonist phenylephrine was more effective in constricting the coronary vasculature of diabetic dogs than that of healthy animals (Fig.4). This finding is in line with our earlier in vivo results indicating that the conductance of the normal coronary arterial bed is increased, whilst the conductivity of diabetic coronary vessels is decreased, by sympathetic cardiac nerve stimulation [48]. Our observation is in accordance with the data of others who demonstrated similar $\alpha$-adrenergic hyper-responsiveness in other regions of the diabetic vasculature [11, 49, 50]. This could be explained by diminished adrenergic ennervation $[50,51]$ that may result in denervation supersensitivity [52]. Furthermore, an imbalance detected among the synthesized prostaglandins is supposed to contribute to the more expressed vasoconstriction provoked by phenylephrine in the coronary arterial bed.
That imbalance, which was confirmed by the increased basal $\mathrm{TXA}_{2}$ synthesis from diabetic arteries, might be masked under circulatory circumstances at rest when $\mathrm{PGI}_{2}$ production is not altered. However, during adrenergic stimulation - which has no effect on $\mathrm{PGI}_{2}$ synthesis or even depresses it - the oxygen supply due to the diminished vasodilatory capacity would be reduced, rather than increased, serving as a reliable contribution to the high incidence and severity of ischaemic heart disease in diabetes mellitus.

\section{References}

1. Busse R, Bassenge E (1984) Modulation des Koronargefäßtonus: Molekuläre und zelluläre Mechanismen. Z Kardiol 73: 477-491

2. Moncada S (1982) Biological importance of prostacyclin. Br J Pharmacol 76: 3-31

3. Brody MJ, Dixon RL (1964) Vascular reactivity in experimental diabetes mellitus. Circ Res 14: 494-501

4. Bohlen HG, Hankins KD (1982) Early arteriolar and capillary changes in streptozotocin-induced diabetic rats and intraperitoneal hyperglycaemic rats. Diabetologia 22: $344-348$

5. Mueller SM, Mueller RM, Ertel PJ (1982) Sympathetic and vascular dysfunction in early experimental juvenile diabetes mellitus. Am J Physiol 243: H139-144

6. Fortes ZB, Garcia-Leme J, Scivoletto R (1983) Vascular reactivity in diabetes mellitus: possible role of insulin on the endothelial cell. Br J Pharmacol 83: 635-643

7. Sullivan S, Sparks HV (1979) Diminished contractile response of aortas from diabetic rabbits. Am J Physiol 236: H301-306

8. Christlieb AR (1974) Renin, angiotensin and norepinephrine in alloxan-diabetes. Diabetes 23: 962-970

9. Jackson CV, Carrier GO (1981) Supersensitivity of isolated mesenteric arteries to noradrenaline in the long-term experimental diabetic rat. J Auton Pharmacol 1: 399-405

10. Zitnay M (1986) Augmented adrenergic responses of diabetic carotid arteries are dependent on the endothelium. Circulation 74: 413 (Abstract)

11. Owen MP, Carrier GO (1980) Calcium dependence of norepinephrine-induced vascular contraction in experimental diabetes. J Pharmacol Exp Ther 212: 253-258

12. MacLeod KM, McNeill JH (1985) The influence of chronic experimental diabetes on contractile responses of rat isolated blood vessels. Can J Physol Pharmacol 63: 52-577

13. Cseuz R, Wenger TL, Kunos G, Szentiványi M (1973) Changes of adrenergic reaction pattern in experimental diabetes. Endocrinology 93: 752-755

14. Sterin-Borda L, Borda ES, Gimeno M, Lazzari MA, DelCastillo E, Gimeno AL (1982) Contractile activity and prostacyclin generation in isolated coronary arteries from diabetic dogs. Diabetologia 22: 56-59

15. Roth DM, Reibel DK, Lefer AM (1983) Vascular responsiveness and eicosanoids production in diabetic rats. Diabetologia 24: 372-376

16. Palik I, Koltai MZ, Hadházy $P$, Malomvölgyi $B$, Wagner $M$, Pogátsa $G$ (1982) Effects of prostaglandins $E_{2}, I_{2}$ and $F_{2 \alpha}$ on the tone of isolated coronary arteries from alloxan-diabetic dogs. Prostaglandins Leukotrunes Med 8: 607-617

17. Harrison HE, Reece AH, Johnson M (1978) Decreased vascular prostacyclin in experimental diabetes. Life Sci 23: 354-356

18. Rogers SP, Larking S (1981) Production of 6-oxo $\mathrm{PGF}_{1 \alpha}$ by rat aorta, influence of diabetes, insulin treatment and caloric deprivation. Diabetes $30: 19-33$

19. Rösen P, Rösen R, Hohl C, Reinauer H, Klaus W (1984) Reduced transcoronary exchange and prostaglandin synthesis in the diabetic rat heart. Am J Physiol 247: H372-376 
20. Wey HE, Subbiah MTR (1984) Altered aortic prostaglandin synthesis in a mild form of diabetes and the influence of dietary cholesterol. J Lab Clin Med 104: 312-320

21. Subbiah MTR, Deitemeyer D (1980) Altered synthesis of prostaglandins in platelet and aorta from spontaneously diabetic Wistar rats. Biochem Med 23: 231-235

22. Ganda MP (1980) Pathogenesis of macrovascular disease in the human diabetes. Diabetes 29: 931-942

23. Wennmalm A, Brundin T (1978) Prostaglandin mediated inhibition of noradrenaline release IV. Prostaglandin synthesis is stimulated by myocardial adrenoceptors differing from the $\alpha$ and $\beta$ type. Acta Physiol Scand 102: 374-381

24. Conard V, Franckson JRM, Bastenie PA, Kestens J, Kovács L (1953) Etude critique du triangle d, hyperglycemie intraveineux chez $\mathrm{l}$, homme et determination $\mathrm{d}$, un coefficient $\mathrm{d}$, assimilation glucidique. Arch Int Pharmacodyn Ther 93: 277-292

25. Trinder $P$ (1969) Determination of blood glucose using an oxydase-peroxydase system with a non-carcinogenic chromogen. J Clin Pathol 22: 158-161

26. Fawcett JK, Scott JE (1960) A rapid and precise method for the determination of urea. J Clin Pathol 13: 156-159

27. Neuweiler W (1933) Quantitative Bestimmung der Acetonkörper im Blut mittels des Stufenphotometers. Klin Wochenschr 12: $869-890$

28. Boeynaems JM, Galand N, Ketelbant P (1985) Prostacyclin production by the deendothelialized rabbit aorta. Klin Invest 76 : 7-14

29. Jeremy JY, Mikhailidis DP, Dandona P (1985) Adrenergic modulation of vascular prostacyclin $\left(\mathrm{PGI}_{2}\right)$ secretion. cur J Pharmacol 114: 33-40

30. Valentovic MA, Lubawy WC (1983) Impact of insulin or tolbutamide treatment on ${ }^{14} \mathrm{C}$ arachidonic acid conversion to prostacyclin and/or thromboxane in lungs, aortas and platelets of streptozotocin induced diabetic rats. Diabetes 32: 846-851

31. Colwell JA, Wincour PD, Lopes-Virella M, Halushka PV (1983) New concepts about the pathogenesis of atherosclerosis in diabetes mellitus. Am J Med 75: 67-81

32. Johnson M, Harrison HE, Raferty AT, Elder JB (1979) Vascular prostacyclin may be reduced in diabetes in man. Lancet $\mathrm{I}$ : 325-326

33. Carreras LO, Chamome DAF, Klerck P, Vermylen J (1980) Decreased vascular $\mathrm{PGI}_{2}$ release in diabetic rats. Stimulation of $\mathrm{PGI}_{2}$ release in normal and diabetic rats by the antithrombotic compound BAY 6575. Thromb Res 19: 663-670

34. McNamara DB, Donath GR, Kadowitz PJ, Hyman AL, Rush DS, Kerstein MD (1986) Prostacyclin synthetase activity in human diabetic and non-diabetic vascular tissue. J Vasc Surg 4: 63-67

35. Myers TO, Messina EJ, Rodrigues AM, Gerritsen ME (1985) Altered aortic and cremaster muscle prostaglandin synthesis in diabetic rats. Am J Physiol 249: E374-379

36. Gerrard JM, Stuart MJ, Rao GHR, Steffes MW, Mauer SM, Brown DM, White JG (1980) Alterations in the balance of prostacyclin and thromboxane synthesis in diabetes. J Lab Clin Med 95: 950-955

37. Belo SE, Talesnik J (1982) Coronary vasoconstrictor and vasodilator actions of arachidonic acid in the isolated perfused heart of the rat. Br J Pharmacol 75: 269-286

38. Sterin-Borda L, Franchi AM, Borda ES, DelCastillo E, Gimeno MF, Gimeno AL (1984) Augmented thromboxane generation by mesenteric arteries from pancreatectomized diabetic dogs is concident with the vascular tone enhancement evoked by Na-arachidonate and prostacyclin. Eur J Pharmacol 103:211-221
39. Horrobin DF (1980) A new concept of lifestyle-related cardiovascular disease: the importance of interactions between cholesterol, essential fatty acids, prostaglandin $\mathrm{E}_{1}$ and thromboxane $\mathrm{A}_{2}$. Med Hypotheses 15: 953-961

40. Karpen CW, Pritchard KA, Merola AJ, Panganamala RV (1982) Alterations of the prostacyclin-thromboxane ratio in streptozotcin induced diabetic rats. Prostaglandins Leukotrienes Med 8: 93-103

41. Fujii K, Soma M, Huang YS, Manku MS, Horrobin DF (1986) Increased release of prostaglandins from the mesenteric vascular bed of diabetic animals: the effects of glucose and insulin. Prostaglandins Leukotrienes Med 24: 151-161

42. Gimeno AL, Sterin-Borda L, Borda ES, DelCastillo EJ, Gimeno MF (1983) Arachidonate evokes constriction of coronary and mesenteric arteries isolated from diabetic dogs. In: Samuelsson B, Paoletti R, Ramwell P (eds) Advances in prostaglandin thromboxane and leukotriene research, Vol 12. Raven Press, New York, pp 235-240

43. Jeremy JY, Thompson CS, Mikhailidis DP, Dandona P (1986) Duration and not severity of diabetes mellitus determines effects on prostacyclin synthesis in the rat aorta, penis and bladder. Prog Lipid Res 25: 507-509

44. Needleman P, Minkes M, Raz A (1976) Thromboxanes: selective biosynthesis and distinct biological properties. Science 193: 163-165

45. Stewart D, Pountney E, Fitchett D (1984) Norepinephrine stimulated vascular prostacyclin synthesis. Receptor dependent calcium channels control prostaglandin synthesis. Can J Physiol Pharmacol 62: 1341-1347

46. Peredo H, Agostini M, Gimeno MF, Sterin-Borda DE (1984) Hypersensitivity to norepinephrine in vasa deferentia from diabetic rats. Possible participation of metabolic products of arachidonic acid. Prostaglandins Leukotrienes Med 15: 229-239

47. Rösen P, Schrör K (1980) Increased prostacyclin release from perfused hearts of acutely diabetic rats. Diabetologia 18: 391-394

48. Koltai MZ, Jermendy GY, Kiss V, Wagner M, Pogátsa G (1984) The effects of sympathetic stimulation and adenosine concoronary circulation and heart function in diabetes mellitus. Acta Physiol Hung 63: 119-125

49. Scarborough NL, Carrier GO (1983) Increased $\alpha_{2}$ adrenoceptor mediated vascular contraction in diabetic rats. J Auton Pharmacol 3: 177-183

50. Amenta D, Cavallotti C, Collier WL, deRossi M, Ricci A, Amenta F (1987) Noradrenergic innervation of the superior mesenteric artery in streptozotocin-diabetic rats. Acta Histochem Cytochem 20: 177-184

51. Felten SY, Petersen RG, Shea PA, Besch HR, Felten DL (1982) Effect of streptozotocin diabetes on the noradrenergic innervation of the heart: a longitudinal histofluorescence and neurochemical study. Brain Res Bull 8: 593-607

52. Trendelenburg U (1966) Mechanisms of supersensitivity and subsensitivity to sympathomimetic amines. Pharmacol Rev 18: 629-640

Received: 3 February 1988

and in revised form: 19 July 1988

Dr. M.Z. Koltai

National Institute of Cardiology

P.O. Box $9-88$

H-1450 Budapest

Hungary 